\section{CHEMICAL MODIFICATION OF ANTIBIOTIC STREPTONIGRIN; SYNTHESIS AND PROPERTIES OF $2^{\prime}$-DECARBOXY- 2'-AMINOSTREPTONIGRIN (STREPTONIGRONE-2'-IMINE)}

\section{V. Tolstikov, M. N. Preobrazhenskaya, J. Balzarini ${ }^{\dagger}$ and E. De ClercQ ${ }^{\dagger}$ \\ Institute of New Antibiotics of Russian Academy of Medical Sciences, \\ Moscow 119867, Russia \\ ${ }^{\dagger}$ Rega Institute for Medical Research, Katholieke Universiteit Leuven, B-3000 Leuven, Belgium}

(Received for publication November 25, 1991)

Whereas the cytostatic properties of the antibiotic streptonigrin (1) and its amides and esters have been studied $^{1 \sim 4)}$, structure-activity relationships for other derivatives of 1 , as well as for derivatives of antibiotic streptonigrone (2), which is a minor component of the streptonigrin complex ${ }^{5}$, remain to be investigated. In this paper we describe the synthesis of $2^{\prime}$-decarboxy-2'-aminostreptonigrin (8), which can be considered as an analogue of streptonigrone.

1 was converted to the mixed anhydride (3) (1 equiv ClCOOEt; 1.1 equiv $\mathrm{Et}_{3} \mathrm{~N} ; \mathrm{THF} ; 0^{\circ} \mathrm{C} ; 0.5$ hour), which under the action of $\mathrm{NaN}_{3}$ ( 3 equiv $\mathrm{H}_{2} \mathrm{O} ; 0^{\circ} \mathrm{C} ; 1$ hour) afforded, after extraction with EtOAc, the corresponding azide (4), (IR $v_{\text {max }}$ $\left.\left(\mathrm{CHCl}_{3}\right) \mathrm{cm}^{-1} 2250\left(\mathrm{~N}_{3}\right), 1750(\mathrm{C}=\mathrm{O})\right)$, which was immediately used in the next step of conversion (see Scheme 1). All the new compounds were separated by TLC using Kieselgel 60 (Merck) plates in chloroform - acetone - methanol, 8:1:1 mixture.

Decomposition of $\mathbf{4}$ in anhydrous conditions (dry toluene, reflux for 2 hours) led via streptonigrin-2'decarboxy-2'-isocyanate (5) to the dimer $6(70 \%$; MP $164 \sim 165^{\circ} \mathrm{C}$; Rf $0.60 ;{ }^{1} \mathrm{H}$ NMR (Varian VXR 400 instrument, $\left.400 \mathrm{MHz}, \mathrm{CDCl}_{3}\right) \delta 8.78(1 \mathrm{H}, \mathrm{d}$, $\left.J_{3,4}=8 \mathrm{~Hz}, 4-\mathrm{H}\right), 8.77(1 \mathrm{H}, \mathrm{d}, 4-\mathrm{H}), 8.32(1 \mathrm{H}, \mathrm{d}$, $3-\mathrm{H}), 8.27(1 \mathrm{H}, \mathrm{d}, 3-\mathrm{H}), 7.05\left(1 \mathrm{H}, \mathrm{d}, J_{11^{\prime}, 12^{\prime}}=8.5 \mathrm{~Hz}\right.$, $12^{\prime}-\mathrm{H}$ or $\left.11^{\prime}-\mathrm{H}\right), 6.99\left(1 \mathrm{H}, \mathrm{d}, 12^{\prime}-\mathrm{H}\right.$ or $\left.11^{\prime}-\mathrm{H}\right), 6.72$ $\left(2 \mathrm{H}, \mathrm{s}, 8^{\prime}-\mathrm{OH}, 2\right.$-groups $), 6.70\left(1 \mathrm{H}, \mathrm{d}, 11^{\prime}-\mathrm{H}\right.$ or $\left.12^{\prime}-\mathrm{H}\right), 6.65\left(1 \mathrm{H}, \mathrm{d}, 11^{\prime}-\mathrm{H}\right.$ or $\left.12^{\prime}-\mathrm{H}\right), 6.00(4 \mathrm{H}, \mathrm{brs}$, 7- $\mathrm{NH}_{2}, 2$-groups), $5.10\left(4 \mathrm{H}\right.$, brs, $5^{\prime}-\mathrm{NH}_{2}, 2$ groups), $4.08\left(3 \mathrm{H}, \mathrm{s},-\mathrm{OCH}_{3}\right), 4.07\left(3 \mathrm{H}, \mathrm{s},-\mathrm{OCH}_{3}\right)$, $3.99\left(3 \mathrm{H}, \mathrm{s},-\mathrm{OCH}_{3}\right), 3.98\left(3 \mathrm{H}, \mathrm{s},-\mathrm{OCH}_{3}\right), 3.97$ $\left(3 \mathrm{H}, \mathrm{s},-\mathrm{OCH}_{3}\right), 3.95\left(3 \mathrm{H}, \mathrm{s},-\mathrm{OCH}_{3}\right), 2.09(3 \mathrm{H}, \mathrm{s}$,
3'- $\left.\mathrm{CH}_{3}\right), 2.04\left(3 \mathrm{H}, \mathrm{s}, 3^{\prime}-\mathrm{CH}_{3}\right)$; CI-MS (Jeol JMSDX 300 instrument with $\mathrm{NH}_{3}$ as a reagent gas) $m / z 504\left(\frac{M}{2}+\mathrm{H}, \mathrm{C}_{25} \mathrm{H}_{22} \mathrm{~N}_{5} \mathrm{O}_{7}\right), 475\left(\frac{\mathrm{M}}{2}-\mathrm{CO}\right.$, $\mathrm{C}_{24} \mathrm{H}_{21} \mathrm{~N}_{5} \mathrm{O}_{6}$ ); EI-MS (Varian-MAT-112 spectrometer at $210 \sim 230^{\circ} \mathrm{C}$ ion source and $70 \mathrm{eV}$ electron energy, samples being introduced by direct insertion) $m / z 503.1\left(\left(\frac{\mathrm{M}}{2}\right)^{+}, \mathrm{C}_{25} \mathrm{H}_{21} \mathrm{~N}_{5} \mathrm{O}_{7}\right)$. Doubling of the signals of all protons in the ${ }^{1} \mathrm{H}$ NMR spectrum of 6 demonstrates the absence of symmetry in the dimer structure (similar to pyridyl-2isocyanate dimer $^{6)}$ ).

Decomposition of 4 in boiling tert-BuOH (4 hours, evaporation, isolation by preparative TLC) gave 2 '-decarboxy-2'-(tert-butyloxycarbonylamino)streptonigrin (7), amine 8 and dimer 6. Compound 7 was obtained in $40 \%$ yield (MP $162 \sim 164^{\circ} \mathrm{C}(\mathrm{dec})$; Rf $0.85 ;{ }^{1} \mathrm{H} \mathrm{NMR}\left(400 \mathrm{MHz}, \mathrm{DMSO}-d_{6}\right) \delta 8.65(1 \mathrm{H}$, d, $\left.J_{3,4}=8 \mathrm{~Hz}, 4-\mathrm{H}\right), 8.15(1 \mathrm{H}, \mathrm{d}, 3-\mathrm{H}), 6.67(1 \mathrm{H}, \mathrm{d}$, $J_{11^{\prime}, 12^{\prime}}=8.5 \mathrm{~Hz}, 12^{\prime}-\mathrm{H}$ or $\left.11^{\prime}-\mathrm{H}\right), 6.45\left(1 \mathrm{H}, \mathrm{d}, 11^{\prime}-\mathrm{H}\right.$ or $\left.12^{\prime}-\mathrm{H}\right), 3.71\left(3 \mathrm{H}, \mathrm{s},-\mathrm{OCH}_{3}\right), 3.69\left(3 \mathrm{H}, \mathrm{s},-\mathrm{OCH}_{3}\right)$, $3.67\left(3 \mathrm{H}, \mathrm{s},-\mathrm{OCH}_{3}\right), 1.92\left(9 \mathrm{H}, \mathrm{s}, \mathrm{O}-\mathrm{C}\left(\mathrm{CH}_{3}\right)_{3}\right), 1.86$ $\left.\left(3 \mathrm{H}, \mathrm{s}, 3^{\prime}-\mathrm{CH}_{3}\right)\right)$. Amine 8 was obtained in $30 \%$ yield (MP $192 \sim 194^{\circ} \mathrm{C} ; \operatorname{Rf} 0.40 ;{ }^{1} \mathrm{H}$ NMR $(400 \mathrm{MHz}$ $\left.\mathrm{CDCl}_{3}\right) \delta 8.77\left(1 \mathrm{H}, \mathrm{d}, J_{3,4}=8 \mathrm{~Hz}, 4-\mathrm{H}\right), 8.32(1 \mathrm{H}$, d, $3-\mathrm{H}), 6.81\left(1 \mathrm{H}, \mathrm{d}, J_{11^{\prime} 12^{\prime}}=8.5 \mathrm{~Hz}, 12^{\prime}-\mathrm{H}\right), 6.63$ $\left(1 \mathrm{H}, \mathrm{d}, 11^{\prime}-\mathrm{H}\right), 5.04\left(2 \mathrm{H}\right.$, br s, $\left.5^{\prime}-\mathrm{NH}_{2}\right), 4.05(3 \mathrm{H}, \mathrm{s}$, $\left.-\mathrm{OCH}_{3}\right), 3.96\left(3 \mathrm{H}, \mathrm{s},-\mathrm{OCH}_{3}\right), 3.93\left(3 \mathrm{H}, \mathrm{s},-\mathrm{OCH}_{3}\right)$, $1.93\left(3 \mathrm{H}, \mathrm{s}, 3^{\prime}-\mathrm{CH}_{3}\right) ;{ }^{13} \mathrm{C}$ NMR (Varian XL 100, $\left.100 \mathrm{MHz}, \mathrm{CDCl}_{3}\right) \delta 179.8(\mathrm{C}-8), 177.1(\mathrm{C}-5), 161.1$ (C-8a), $152.6\left(\mathrm{C}-10^{\prime}\right), 148.4\left(\mathrm{C}-2^{\prime}\right), 147.3\left(\mathrm{C}-8^{\prime}\right), 143.9$ (C-5'), 140.3 (C-2), 137.2 (C-7), 136.9 (C-3'), 136.4 (C-9'), 132.5 (C-6), 128.3 (C-6'), 124.9 (C-4), 125.4 (C-4a), $124.3(\mathrm{C}-3), 121.9\left(\mathrm{C}-12^{\prime}\right), 119.6\left(\mathrm{C}-4^{\prime}\right) 115.1$ $\left(\mathrm{C}-7^{\prime}\right), 103.6\left(\mathrm{C}-11^{\prime}\right), 59.8\left(-\mathrm{OCH}_{3}\right), 59.1\left(-\mathrm{OCH}_{3}\right)$, $54.9\left(-\mathrm{OCH}_{3}\right), 13.7\left(3^{\prime}-\mathrm{CH}_{3}\right)$; CI-MS $m / z 477(\mathrm{M}$, $\left.\mathrm{C}_{24} \mathrm{H}_{23} \mathrm{~N}_{5} \mathrm{O}_{6}\right)$ ). Dimer 6 was isolated in $10 \%$ yield. Treatment of 4 with a mixture of $\mathrm{CF}_{3} \mathrm{COOH}-\mathrm{H}_{2} \mathrm{O}$ (1:5, steam bath; 1 hour) with subsequent evaporation and neutralization (1.1 equiv $\mathrm{Et}_{3} \mathrm{~N}$ in $\mathrm{CHCl}_{3} ; 0^{\circ} \mathrm{C} ; 0.5$ hour), extraction with EtOAc and washing $\left(5 \%\right.$ aq $\left.\mathrm{NaHCO}_{3}\right)$ afforded the amine 8 in $65 \%$ yield. Amine 8 was obtained also by cleavage of 6 in $\mathrm{CF}_{3} \mathrm{COOH}-\mathrm{CH}_{2} \mathrm{Cl}_{2}\left(1: 1 ; 0^{\circ} \mathrm{C}\right.$ to $20^{\circ} \mathrm{C} ; 2$ hours) in $80 \%$ yield. By using diphenylphosphoryl azide (DPPA) ${ }^{7)}$ for the direct conversion of 1 , we prepared amine 8 in $40 \%$ yield (1.5 equiv DPPA; 1.5 equiv $\mathrm{Et}_{3} \mathrm{~N}$; dioxane - tert -BuOH $(5: 1)$; $80^{\circ} \mathrm{C} ; 36$ hours) (see Scheme 1). Amine 8, under the action of $0.5 \mathrm{M} \mathrm{HCl}$ in $\mathrm{MeOH}$, afforded the hydrochloride (9) $\left(95 \%\right.$; MP $\left.235^{\circ} \mathrm{C}(\mathrm{dec})\right)$.

The inhibitory effects of compound $\mathbf{8}$, its hydrochloride 9 and streptonigrone 2 in comparison 
Scheme 1.

$\mathrm{STN}-\mathrm{COOH} \longrightarrow\left[\begin{array}{r}\mathrm{STN}-\mathrm{C}=0 \\ \mathrm{O} \\ \mathrm{EtO}-\mathrm{C}=\mathrm{O}\end{array}\right] \longrightarrow \mathrm{STN}-\mathrm{CON}_{3}$

1

3

4

(2)

1

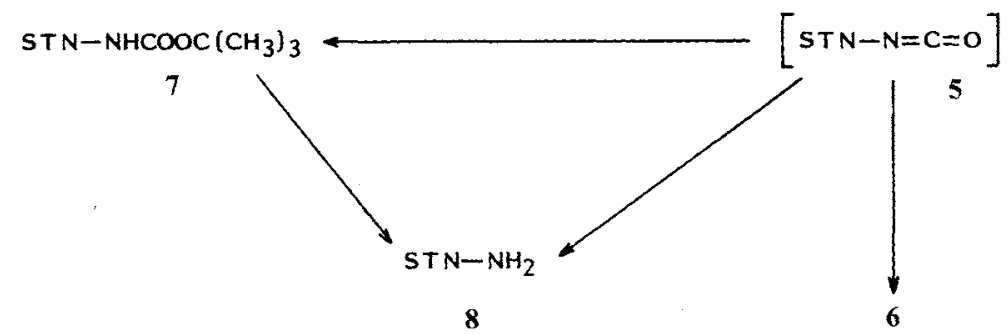

STN =<smiles></smiles>

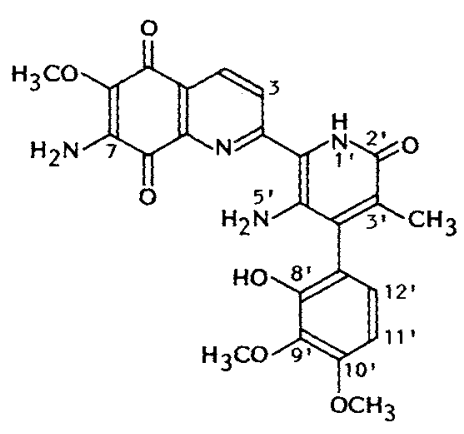

2

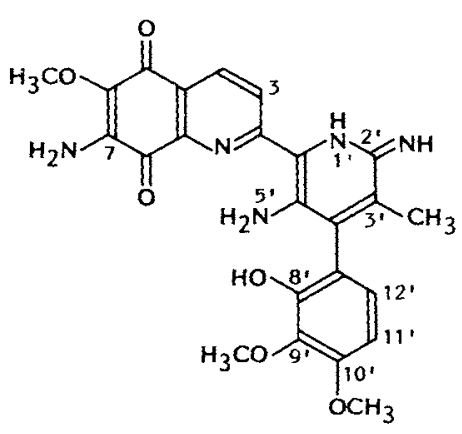

8 
Table 1. Inhibitory effects of streptonigrin (1), streptonigrone (2) and derivatives 8 and $\mathbf{9}$ on the proliferation of murine leukemia (L1210), human T-lymphoblast (MOLT-4F) and human T-lymphocyte (MT-4) cells.

\begin{tabular}{cccc}
\hline & \multicolumn{3}{c}{ Inhibition of tumor cell proliferation $\mathrm{IC}_{50} *(\mu \mathrm{M} / \mathrm{ml})$} \\
\cline { 2 - 4 } Compound & $\mathrm{L} 1210$ & MOLT-4F & MT-4 \\
\hline $\mathbf{1}$ & $0.044 \pm 0.009$ & $0.004 \pm 0.0004$ & $0.0002 \pm 0.00001$ \\
$\mathbf{2}$ & $2.57 \pm 0.28$ & $2.29 \pm 0.46$ & $1.83 \pm 0.06$ \\
$\mathbf{8}$ & $2.46 \pm 0.24$ & $2.29 \pm 0.03$ & $0.055 \pm 0.035$ \\
$\mathbf{9}$ & $2.91 \pm 0.08$ & $2.68 \pm 0.26$ & $0.74 \pm 0.23$ \\
\hline * $50 \%$ inhibitory concentrations, or concentrations required to inhibit cell proliferation by \\
$50 \%$.
\end{tabular}

with compound $\mathbf{1}$, which can be considered as 2 -imine of streptonigrone (see Scheme 2), on the proliferation of murine leukemia (L1210), human T-lymphoblast (MOLT-4F) and human T-lymphocyte (MT-4) cells are shown in the Table 1 . Compounds 8 and 9 were less cytotoxic than 1, the $\mathrm{IC}_{50}$ values for 2,8 and 9 being similar. Compounds $\mathbf{8}, \mathbf{9}$ and $\mathbf{2}$ did not prove effective against HIV-1 or HIV-2 induced cytopathogenicity in MT-4 cells at subtoxic concentrations. The assays for measuring inhibition of tumor cell growth L1210, MOLT-4F, MT-4 and anti-HIV activity in MT-4 cells were performed as previously described ${ }^{8)}$.

\section{Acknowledgments}

In the USSR this research was supported by Grant from the All Union Anti-Aids Programm, it was also supported in part by Grant from the Belgian "Nationaal Fonds voor Wetenschappelijk Onderzoek" Project No. 7.0049.90 and by the AIDS Basic Research Programme of the European Community.

\section{References}

1) Take, Y.; Y. Inouye, S. Nakamura, H. S. AllaudeEn \& A. Kubo: Comparative studies of the inhibitory properties of antibiotics on human immunodeficiency virus and avian myeloblastosis virus reverse transcriptases and cellular DNA polymerases. J. Antibiotics 42: 107 115, 1989

2) TAKE, Y.; T. Kubo, E. TAKEMORI, Y. INOUYE, S. Nakamura, T. Nishimura, H. SuzukI \& $H$.
YAMAGUCHI: Biological properties of streptonigrin derivatives. III. In vitro and in vivo antiviral and antitumor activities. J. Antibiotics 42: $968 \sim 976,1989$

3) Tolstikov, V. V.; N. V. Kozlova, I. V. YartSEVA, Y. V. DObrynin, E. A. Synyagina, T. G. Nikolayeva, V. E. Finko, A. A. Arutunyan, R. G. Melik-Ogandzhanyan \& M. N. PreobrazhensKAYA: Synthesis of amides and esters of antibiotic bruneomycin (streptonigrin) and study of their cytotoxyc and antiretroviral activities. Khim. Pharm. Zhurn. 24 (2): $130 \sim 132,1990$

4) Tolstikov, V. V;; N. V. Kozlova, I. V. Yartseva \& M. N. Preobrazhenskaya: "Chimeric" antibiotics, daunorubicin and its analogues $\mathrm{N}$-acylated with bruneomycin (streptonigrin). Bioorg. Khim. 15: $277 \sim 280,1989$

5) Herlt, A. J.; R. W. Rickards \& J.-P. WU: The structure of streptonigrone, and a comment on the biosynthesis of the streptonigrin antibiotics. J. Antibiotics 38: 516 518, 1985

6) L'Abbe, G.; L. van Meervelt, P. Brems \& L. P. DECLERCQ: Crystal structure of 3-tert-butylimino2,3-dihydroimidazo(1.2-a)pyridin-2-one. Bull. Soc. Chim. Belg. 96: 751 756, 1987

7) Shorri, T.; K. NinomiYa \& S. Yamada: Diphenylphosphoryl azide. A new convenient reagent for a modified curtius reaction and for the peptide synthesis. J. Am. Chem. Soc. 94: 6203 6205, 1972

8) Balzarini, J.; M. Baba, R. Pauwels, P. Herdewij, G. S. Ward, M. J. Robins \& E. De ClercQ: Potent and selective activity of $3^{\prime}$-azido-2,6-diaminopurine2',3'-dideoxyriboside. $3^{\prime}$-fluoro-2,6-diaminopurine$2^{\prime}, 3^{\prime}$-dideoxyriboside, and $3^{\prime}$-fluoro-2',3'-dideoxyguanosine against human immunodeficiency virus. Mol. Pharmacol. 33: 243 249, 1988 